\title{
Peran Lembaga Penjamin Simpanan Terhadap Klaim Dana Nasabah Bank Likuidasi
}

\author{
Yennie Agustin M.R. \\ Bagian Hukum Keperdataan Fakultas Hukum Universitas Lampun \\ Email : yennie.agustin@fh.unila.ac.id
}

\begin{abstract}
Abstrak
Lembaga Penjamin Simpanan merupakan penyempurnaan dari program penjaminan pemerintah terhadap seluruh kewajiban bank (blanket guarantee) atas dana nasabah bank yang pernah diterapakan sebelum berlakunya Undang-Undang Nomor 24 Tahun 2004 tentang Lembaga Penjamin Simpanan (UU LPS). Fungsi utama dari lembaga ini adalah meningkatkan kepercayaan nasabah terhadap industri perbankan yaitu dengan adanya jaminan pengembalian dana yang disimpan serta turut serta memelihara stabilitas sistem perbankan sesuai kewenangannya. Keberadaan Lembaga Penjamin Simpanan merupakan bagian dari kelengkapan instrumen pemerintah dalam menciptakan jejaring pengaman perbankan (banking safety net) dan pengaman sistem keuangan (financial safety net). Sebagai banking safety net dilakukan melakui program penjaminan dan penanganan bank gagal (bank yang dilikuidasi), sementara sebagai financial safety net diwujudkan dalam pemanfaatan surplus dan akumulasi premi.
\end{abstract}

\section{Kata Kunci : Peran Lembaga Penjamin Simpanan, Likuidasi Bank}

\section{Pendahuluan}

Industri Perbankan merupakan salah satu komponen yang sangat menentukan dalam perekonomian nasional demi menjaga keseimbangan, kemajuan dan kesatuan ekonomi nasional. Stabilitas industri perbankan sangat mempengaruhi stabilitas perekonomian secara keseluruhan.

Kestabilan industri perbankan merupakan salah satu kunci dalam menjaga kepercayaan masyarakat dapat diperoleh dengan adanya kepastian hukum dalam pengaturan dan pengawasan bank serta penjaminan simpanan nasabah bank untuk meningkatkan kelangsungan usaha bank secara sehat. Kelangsungan usaha bank secara sehat dapat menjamin keamanan simpanan para nasabahnya serta meningkatnya peran bank sebagai penyedia dana pembangunan dan pelayanan jasa perbankan. Oleh karena itu, baik pemilik dan pengelola bank maupun otoritas yang terlibat dalam pengaturan dan/atau pengawasan bank sudah selayaknya dapat mewujudkan kepercayaan masyarakat dengan penjaminan seluruh kewajiban bank.

Kepercayaan masyarakat akan dunia perbankan mulai menurun yaitu pada tahun 1998 saat krisis moneter dan perbankan menghantam Indonesia yang ditandai dengan dilikuidasinya 16 bank. Untuk mengatasi krisis yang terjadi, pemerintah mengeluarkan beberapa kebijakan diantaranya memberikan jaminan atas seluruh kewajiban bank, termasuk simpanan masyarakat 
(blanket guarantee). ${ }^{1} \quad$ Dalam pelaksanaannya, blanket guarantee memang dapat menumbuhkan kembali kepercayaan masyarakat terhadap industri perbankan, namun ruang lingkup penjaminan yang terlalu luas menyebabkan timbulnya moral hazard baik dari sisi pengelola bank maupun masyarakat.

Belajar dari pengalaman banyak negara dan lembaga internasional yang mewadahi para penjamin simpanan (International Associate of Deposit Insurance/IADI) dari beberapa negara, maka pada tanggal 22 September 2004 Presiden RI mengesahakan pelaksanaan UU LPS untuk menguatkan kondisi moneter saat itu. Maksud dari pembentukan lembaga penjamin ini adalah untuk mengurangi risiko sistemik yang timbul akibat rush $^{2}$ dana nasabah yang bisa melumpuhkan sektor perbankan nasional. Pendirian LPS bertujuan melindungi simpanan nasabah bank di Lembaga Perbankan.

UU LPS merupakan pengganti program blanket guarantee yang mengatur adanya skim penjaminan simpanan nasabah yang terbatas tetapi dapat mencakup sebanyakbanyaknya nasabah. Setiap bank yang menjalankan usahanya di Indonesia diwajibkan untuk menjadi peserta dan membayar premi penjaminan. Dalam hal bank tidak dapat melanjutkan usahanya dan harus dicabut izin usahanya, Lembaga Penjamin Simpanan akan

\footnotetext{
1 Adrian Sutendi, Aspek hukum Lembaga Penjamin Simpanan, Jakarta, Sinar Grafika, 2010, hal 5

2 Rush merupakan peristiwa pengambilan dana secara besar-besaran dan tiba-tiba oleh nasabah peyimpan dari bank-bank yang belum dilikuidasi
}

membayar simpanan setiap nasabah bank sampai jumlah tertentu sebagaimana ditetapkan. Adapun simpanan yang dijamin akan diselesaikan melalui proses likuidasi bank. Likuidasi merupakan tindak lanjut dalam penyelesaian bank yang mengalami kesulitan keuangan. ${ }^{3}$

Lemahnya sistem perbankan di Indonesia yang berakibat kebangkrutan dan berujung pada likuidasi bank. Oleh karena itu gagalnya sebuah bank harus dijadikan suatu risiko yang dapat terukur dan rasional. Artinya harus disadari peluang gagalnya suatu bank agar dapat dilakukan perhitungan pencadangan dana dan penanganan bank gagal dapat lebih terorganisir dengan baik. Penerapan prudential banking practisises merupakan andalan bagi upaya pembinaan dan sarana perlindungan kepada masyarakat masih perlu ditingkatkan untuk mencapai sasaran yang diharapkan. Disamping itu pertanggungjawaban terhadap nasabah keuangan nasabah belum menunjukkan kepastian pengembalian dana nasabah bila terjadi krisis perbankan. Oleh karena itu langkah-langkah perlindungan hukum terhadap nasabah seperti yang dilakukan oleh Lembaga Penjamin Simpanan sangat penting dilakukan.

Mengingat fungsinya yang sangat penting yaitu harus independent, transparan, akuntabel dalam menjalankan tugas dan wewenangnya, maka hal ini yang menarik untuk dikaji tentang fungsi dan wewenang Lembaga Penjamin Simpanan, bagaimana perannya terhadap pelaksanaan klaim dana

\footnotetext{
${ }^{3}$ Muhammad Djumhana, Hukum Perbankan Indonesia, Bandung, Citra Aditya Bakti, 2000, hal 152
} 
nasabah bank yang dilikuidasi dan akibat dari batasan kebijakan penjaminan simpanan.

\section{Pembahasan}

\subsection{Fungsi dan Wewenang Lembaga Penjamin Simpanan}

Sesuai dengan Pasal 37 B Undang-Undang Nomor 10 Tahun 1998 tentang Perbankan, setiap bank wajib menjamin dana masyarakat yang disimpan pada bank yang bersangkutan. Untuk menjamin simpanan masyarakat tersebut dibentuk Lembaga Penjamin Simpanan.

Dalam Pasal 12 UU LPS, ketentuan tersebut dipertegas dengan menyebutkan bahwa setiap bank yang melakukan kegiatan usaha di wilayah Republik Indonesia wajib menjadi peserta Lembaga Penjamin Simpanan. Jenis Bank tersebut meliputi Bank Umum dan Bank Perkreditan Rakyat, termasuk bank nasional, bank campuran, bank asing, serta bank konvensional dan bank Syariah.

Lembaga Penjamin Simpanan adalah badan hukum yang menyelenggarakan kegiatan penjaminan atas simpanan nasabah penyimpan, melalui skim asuransi, dana penyangga, atau skim lainnya. ${ }^{4}$ Sedangkan menurut UU LPS, Lembaga Penjamin Penjamin Simpanan adalah badan hukum dan merupakan lembaga independen, transparan, dan akuntabel dalam melaksanakan tugas dan wewenangnya serta bertanggungjawab kepada Presiden.

\footnotetext{
4 Berdasarkan Undang-Undang Nomor 10 Tahun 1998 Pasal 1 ayat(2) tentang Perbankan.
}

\begin{abstract}
Dalam menjalankan fungsi menjamin simpanan nasabah penyimpan, Lembaga Penjamin Simpanan mempunyai tugas merumuskan dan menetapkan kebijakan pelaksanaan penjaminan simpanan dan melaksanakan penjaminan simpanan. Sementara itu, fungsi LPS adalah menciptakan dan memelihara stabilitas sistem keuangan bersama dengan menteri keuangan, Bank Indonesia dan Lembaga Pengawas Perbankan sesuai dengan peran dan tugas masing-masing. 5

Dalam Pasal 4 UU LPS, fungsi Lembaga Penjamin Simpanan adalah:

a. Menjamin simpanan nasabah penyimpan

b. Turut aktif dan memelihara stabilitas sistem perbankan sesuai kewenangannya.
\end{abstract}

Fungsi menjamin simpanan nasabah sebagaimana dimaksud dalam ketentuan ini, tidak terlepas dari sejarah pembentukannya yang pada dasarnya dilakukan sebagai upaya memberikan perlindungan terhadap dua risiko yaitu irration run terhadap bank dan sistemic risk.

Selain itu, fungsi kedua LPS adalah turut aktif dalam memelihara stabilitas sistem perbankan sesuai kewenangannya. $^{6} \quad$ Adapun kewenangannya dijabarkan dalam pasal 6 ayat (2) UU LPS sebagai berikut:

$$
\begin{array}{llcc}
\text { a. } & \text { Mengambil } & \text { alih } & \text { dan } \\
\text { menjalankan } & \text { segala hak } & \text { dan }
\end{array}
$$

5 Zulfi Diane Zaini, Indepensi Bank Indonesia dan Penyelesaian Bank Bermasalah, Bandung, Keni Media, 2012, hal 170.

6 Sentosa Sembiring, Hukum Perbankan Edisi Revisi, Bandung, Mandar Maji, 2012, hal 243 
wewenang pemegang saham, termasuk hak dan wewenang Rapat umum Pemegang Saham.

b. Menguasai dan mengelola aset dan kewajiban bank gagal diselamatkan.

c. Meninjau ulang, membatalkan, mengakhiri dan atau mengubah setiap kontrak yang mengikat bank gagal yang diselamatkan dengan pihak ketiga yang merugikan bank, dan

d. Menjual dan mengalihkan aset bank tanpa persetujuan debitur atau kewajiban bank tanpa persetujuan kreditur.

Jika dilihat dari fungsi, tugas dan wewenang Lembaga Penjamin Simpanan mengadaptasi model yang serupa dengan sistem asuransi dengan prinsip "industri menolong industri", dimana apabila terjadi bank gagal maka wajib ditolong oleh keseluruhan industri perbankan. Selain itu, untuk mendukung keperluan tersebut, seluruh bank wajib membayar kontribusi dan premi kepada Lembaga Penjamin Simpanan. Dalam rangka pelakanaan penjaminan simpanan, Lembaga Penjamin Simpanan melakukan berperan melakukan pembayaran klaim terhadap simpanan nasabah penyimpan dari bank yang dicabut izinnya serta melakukan proses likuidasi bank yang dicabut izinnya. Pembayaran klaim penjaminan kepada para nasabah bank dilakukan dalam waktu singkat, yaitu 90 (sembilan puluh) hari sejak bank dicabut izinnya. Proses pembayaran klaim dirancang secara cepat dengan tujuan untuk memberikan kepastian kepada nasabah bank mengenai status simpanannya. Hal ini diharapkan akan memberikan rasa tenang dan kepastian bagi para nasabah bank yang dicabut izinnya. Dengan peran seperti ini, maka diharapkan Lembaga Penjamin Simpanan akan mendukung stabilitas perbankan secara keseluruhan.

\subsection{Pelaksanaan \\ Penjaminan Lembaga \\ Penjamin Simpanan terhadap Nasabah Bank}

\section{a. Rekonsiliasi dan Verifikasi Simpanan yang dijamin}

Tahap pertama dalam penyelesaian klaim penjaminan oleh LPS terhadap nasabah yaitu rekonsiliasi dan verifikasi simpanan yang dijamin. Rekonsiliasi merupakan proses pencocokan data transaksi keuangan yang diproses dengan sistem yang berbeda berdasarkan dokumen sumber hukum yang sama. Sedangkan verifikasi adalah satu bentuk pengawasan melalui pengujian dokumen keuangan. Rekonsiliasi dan verifikasi simpanan yang dijamin diatur pada Pasal 30 ayat (1) Peraturan Lembaga Penjamin Simpanan Nomor 2/PLPS/2010 yang menyatakan apabila Lembaga Pengawas Perbankan mencabut izin usaha bank, Lembaga Penjamin Simpanan akan segera melakukan rekonsiliasi dan verifikasi terhadap data nasabah penyimpan berdasarkan data per tanggal pencabutan izin usaha untuk menentukan simpanan yang layak dibayar dan simpanan yang tidak layak dibayar.

Lembaga Penjamin Simpanan dapat menunjuk, menguasakan, dan atau menugaskan kepada pihak lain untuk melakukan rekonsiliasi bagi kepentingan dan/atau atas nama Lembaga Penjamin Simpanan. Rekonsiliasi dan verifikasi dilakukan 
secara bertahap berdasarkan rekening yang lebih mudah diverifikasi. Penentuan yang layak dibayar berdasarkan hasil rekonsiliasi dan verifikasi diselesaikan paling lambat 90 (sembilan puluh) hari kerja terhitung sejak izin usaha bank tersebut dicabut.

Proses rekonsiliasi dan verifikasi yang dilakukan Lembaga Penjamin Simpanan terhadap simpanan nasabah dilakukan melalui 3 (tiga) tahap untuk mengetahui secara pasti status simpanan yang diantaranya simpanan layak dibayar, simpanan yang tidak layak dibayar, simpanan di atas maksimum penjaminan, giro/tabungan yang telah ditutup dan deposito yang telah dicairkan namun masih tercatat pada bank sebagai kewajiban negara atau kewajiban lainnya yang tidak termasuk dalam cakupan penjaminan simpanan.

Simpanan layak bayar yang dimaksud adalah simpanan yang berdasarkan hasil rekonsiliasi dan verifikasi yang dilakukan Lembaga Penjamin Simpanan telah memenuhi kriteria layak bayar yang tidak termasuk dalam Pasal 36 Peraturan Lembaga Penjamin Simpanan Nomor 2/PLPS/2010 dinyataka sebagai simpanan yang layak dibayar dapat mengajukan kalim untuk mendapatkan pembayaran atas simpanannya dengan memenuhi syarat dan tata cara yang telah ditetapkan dari pihak Lembaga Penjamin Simpanan.

Mengenai simpanan yang tidak layak dibayar berdasarkan hasil rekonsiliasi dan verifikasi apabila sesuai dengan ketentuan Pasal 40 Peraturan Lembaga Penjamin Simpanan Nomor 2/PLPS/2010 yang menyatakan bahwa klaim penjaminan dinyatakan tidak layak bayar apabila berdasarkan hasil rekonsiliasi dan verifikasi adalah:

a. Data simpanan nasabah dimaksud tidak tercatat dalam bank. Simpanan nasabah yang dinyatakan tercacat pada bank apabila dalam pembukuan bank terdapat data mengenai simpanan tersebut, anatar lain nomor rekening/bilyet, nama nasabah penyimpan, saldo rekening dan informasi lainnya yang lazim berlaku untuk rekening sejenisnya dan/atau terdapat bukti aliran dana yang menunjukkan keberadaan simpanan tersebut.

b. Nasabah penyimpan merupakan pihak yang diuntungkan secara tidak wajar/ nasabah penyimpanan dinyatakan sebagai pihak yang diuntungkan secara tidak wajar apabila nasabah tersebut memperoleh tingkat bunga melebihi maksimum tingkat bunga pinjaman yang ditetapkan Lembaga Penjamin Simpanan sebesar Rp 2.000.000.000,00 (dua milyar rupiah).

c. Nasabah penyimpan merupakan pihak yang menyebabkan keadaan bank menjadi tidak sehat. Suatu pihak yang dinyatakan termasuk sebagai pihak yang menyebabkan keadaan bank menjadi tidak sehat, apabila pihak yang bersangkutan memiliki kewajiban kepada bank yang dikelompokkan dalam kredit macet berdasarkan peraturan perundang-undangan dan saldo kewajiban pihak tersebut lebih besar dari saldo simpanannya. 
Nilai simpanan yang dijamin oleh Lembaga Penjamin Simpanan paling tinggi sebesar Rp 2.000.000.000,00 (dua milyar rupiah) per nasabah. Apabila seseorang nasabah mempunyai beberapa rekening simpanan pada satu bank maka untuk menghitung simpanan yang dijamin saldo seluruh rekening tersebut dijumlahkan. Bagi nasabah penyimpan yang simpanannya di atas maksimum penjaminan atau diatas Rp 2.000.000.000,00 (dua milyar rupiah) bisa mendapatkan simpanannya kembali melaui mekanisme pembayaran kewajiban bank oleh tim likuidasi kepada para kreditur dari hasil pencairan dan/atau penagihan sebagai bagian dari likuidasi bank. Hal ini sesuai dengan Pasal 53 huruf a Undang-Undang Nomor 24 tahun 2004 yang menyatakan bahwa likuidasi bank dilakukan dengan cara pencairan aset dan/atau penagihan piutang kepada para debitur diikuti dengan pembayaran kewajiban bank kepada para kreditur dari hasil pencairan dan/atau penagihan tersebut.

\section{b. Pelaksanaan klaim penjaminan oleh Lembaga Penjamin Simpanan}

Berdasarkan Keputusan Kepala Eksekutif Lembaga Penjamin Simpanan mengenai pelaksanaan pembayaran klaim dilakukan apabila simpanan nasabah telah ditetapkan sebagai simpanan layak dibayar dari hasil rekonsiliasi dan verifikasi yang dilakukan oleh Lembaga Penjamin Simpanan dan dilakukan oleh Bank Pembayar yang ditunjuk oleh LPS. Pembayaran oleh Bank Pembayar dapat dilakukan dengan tatacara yang ditetapakan LPS.
Nasabah yang tidak bisa mendapatkan simpanannya kembali dapat mengajukan keberatan kepada Lembaga Penjamin Simpanan yang didukung bukti, hal ini sesuai dengan Pasal 46 ayat (1) Peraturan Lembaga Penjamin Simpanan Nomor 2/PLPS/2010 jo Undang-Undang Nomor 24 Tahun 2004 yang menyatakan bahwa apabila nasabah penyimpan yang simpanannya tidak layak dibayar merasa dirugikan maka nasabah tersebut dapat mengajukan keberatan kepada Lembaga Penjamin Simpanan yang dilakukan dengan bukti nyata dan jelas atau melakukan upaya hukum melalui pengadilan. Apabila Lembaga Penjamin Simpanan menerima keberatan nasabah penyimpan atau pengadilan mengabulkan upaya hukum nasabah penyimpan maka Lembaga Penjamin Simpanan mengubah status simpanan tersebut (reklasifikasi) dari simpanan yang tidak layak bayar menjadi simpanan yang layak bayar. Lembaga Penjamin Simpanan hanya membayar simpanan sesuai dengan penjaminan serta bunga yang dianggap wajar sejak simpanan nasabah tersebut ditetapkan tidak layak bayar sampai dengan simpanan nasabah dimaksud dibayarkan oleh Lembaga Penjamin Simpanan.

Terhadap kasus likuidasi seperti PT Bank Global ${ }^{7}$ dan PT Bank $\mathrm{IFI}^{8}$ maka ketentuan ketentuan

\footnotetext{
7 Berdasarkan SK Gubernur BI No.7/2/KEP.GBI/2005, tanggal 13 Januari 2005 tentang Pencabutan Izin Usaha PT Bank Global, akibat minimnya aset yang dimiliki dibandingkan kewajibannya, sehingga tidak dapat diselamatkan.

8 Berdasarkan SK Gubernur BI no.11/19/KEP.GBI/2009, tanggal 17 April 2009 tentang Pencabutan Izin Usaha PT Bank IFI karena tidak bisa menambah modal dan menjaga likuiditasnya.
} 
Undang-Undang Nomor 24 Tahun 2004 sudah diterapkan.

Lembaga Penjamin Simpanan menjalankan perannya dalam penyelesaian pembayaran klaim dana nasabah bank yang dilikuidasi. Terkait penyelesaian pembayaran tersebut, mekanisme yang dilakukan Lembaga Penjamin Simpanan adalah:

1) Pembayaran dilakukan oleh bank pembayar yang ditunjuk LPS melalui kantor-kantor cabangnya yang terdekat untuk memudahkan nasabah/kreditur menerima pembayaran dana simpanannya;

2) Dalam memudahkan pelaksanakan pembayarannya, nasabah penyimpan dana dan kreditur diwajibkan membawa dokumen-dokumen dan buktibukti kepemilikan dana disertai dengan identitas diri berupa KTP, SIM atau identitas lainnya;

3) LPS segera mengumumkan pelaksanaan pembayaran, karyawan PT Bank Global dan PT Bank IFI tetap membantu dalam proses penanganan nasabah yang dilakukan LPS.

Berdasarkan hal tersebut maka Lembaga Penjamin Simpanan dapat dikatakan sebagai lembaga asuransi yang didirikan dengan tujuan mengembalikan kepercayaan masyarakat terhadap industri perbankan. Hal tersebut dapat dilihat dari aturan yang sudah ditetapkan dalam Undang-Undang Nomor 4 Tahun 2004 yang menjamin pengembalian dana nasabah sampai sebesar Rp. 2.000.000.000,00 (dua milyar rupiah). Bagi nasabah yang memiliki nilai simpanan yang berada dibawah nilai yang dijaminkan, maka hal ini bisa memberikan rasa aman akan jaminan dana yang disimpannya pada bank. Tetapi bagaimana bagi nasabah yang yang memiliki simpanan diatas jaminan tersebut? Karena walaupun akan tetap memperoleh pengembalian dananya tetapi perlu menunggu proses yang lebih lama yaitu dari hasil penjualan aset bank yang dilikuidasi, artinya kewajiban pembayaran bukan lagi ada di tangan Lembaga Penjamin Simpanan.

\subsection{Akibat Kebijakan Batas Penjaminan Simpanan}

Penerapan kebijakaan yang membatasi kebijakan penjaminan hanya sampai sebesar Rp 2.000.000.000,00 (dua milyar rupiah) bisa menimbulkan beberapa akibat yang mungkin terjadi, antara lain : (1) adanya mutasi rekening sebagai bagian dari konsolidasi bagi penyimpan yang mempunyai beberapa rekening simpanan di suatu bank. Karena batasan penjaminan adalah per nasabah/bank, maka bagi mereka yang memiliki lebih dari satu rekening di bank yang sama akan mengkonsolidasikan simpanannya. Jalan keluarnya adalah memindahkan sebagian simpanannya apabila secara konsolidasi jumlahnya lebih dari Rp 2.000.000.000,00 (dua milyar). Proses pemindahan tersebut dapat dilakukan dengan menindahkan ke bank lain atau mengganti atas nama simpanannya, sehingga tetap terpenuhi persyaratan per nasabah/bank.

Apabila yang akan ditempuh adalah melakukan pemindahan simpanan, maka akan ada lalulintas pemindahan simpanan antar bank. Hal ini tentunya akan menyebabkan adanya pertambahan jumlah rekening pada bak yang akan berdampak kepada kapasitas sistem teknologi yang dimiliki masing-masing bank. 
Dengan pembatasan penjaminan, maka perlindungan terhadap penyimpan dilakukan oleh Lembaga Penjamin Simpanan sampai Rp 2.000.000.000,00 (dua milyar) dan sisanya oleh bank yang bersangkutan. Perbedaannya tentu hanya dalam hal likuidasi penjaminan saja. Bagi simpanan yang dijamin Lembaga Penjamin Simpanan sangat likuid, karena sepuluh hari sejak verifikasi terhadap bank dilikuidasi, LPS sudah harus membayar klaim simpanan para nasabah. Sesuai dengan UndangUndang Nomor 24 Tahun 2004, bagi nasabah penyimpan di atas $\mathrm{Rp}$ 2.000.000.000,00 harus menunggu proses lebih lanjut, yaitu berupa penjualan aset bank yang dilikuidasi. Penjaminan ini tentunya tidak likuid karena proses penjualan aset dimana bagi nasbah penyimpan menduduki prioritas yang keenan dari tujuh prioritas pendistribusian hasil penjualan aset.

Adanya peralihan moral hazard yang semula cenderung ada pada bank-bank yang didominasi penyimpan di atas Rp 2.000.000.000 (dua milyar) ke bank-bank yang memiliki simpanan Rp 2.000.000.000 (dua milyar) yang lebih dominan. Moral hazard tersebut dimungkinkan, mengingat bagi bank-bank yang simpanannya didominasi simpanannya hanya sampai Rp 2.000.000.000,00 sama artinya bahwa penjaminannya adalah blanket guarantee ${ }^{10}$. Sebagaimana lazimnya sebuah blankeet guarantee, maka peluang terjadinya moral hazard menjadi lebih besar. Logikanya kalau seluruh simpanan

\footnotetext{
${ }^{9}$ Adrian Sutendi. Op.cit, hal 79

10 Blankeet guarantee artinya semua simpanan dijamin
}

dijamin untuk apa banknya dikelola dengan baik karena kalupun terjadi sesuatu akan ada yang menjamin. Apabial hal tersebut berpeluang terjadi, diperlukan suatu bentuk pembinaan dan pengawasan yang lebih intensif bagi bank-bank yang atas dasar komposisi simpanannya justru didominasi oleh simpanan sampai Rp 2.000.000.000,00 (dua milyar). Ini memerlukan berbagai langkah persiapan yang lebih memadai mengingat jumlah bank dan Bank Perkreditan Rakyat (BPR) dengan kategori tersebut di atas masih relatif besar.

Keberadaan

Lembaga Penjamin Simpanan merupakan bagian dari kelengkapan instrumen pemerintah dalam menciptakan jejaring pengaman perbankan (banking safety net) dan pengaman sistenm keuangan (financial safety net). Sebagai banking safety net dilakukan melakui program penjaminan dan penanganan bank gagal, sementara sebagai financial safety net diwujudkan dalam pemanfaatan surplus dan akumulasi premi.

\section{Penutup}

1. Peran LPS adalah sebagai badan hukum yang menyelenggarakan kegiatan penjaminan atas simpanan nasabah penyimpan, melalui skim asuransi, dana penyangga, atau skim lainnya.

2. Besarnya nilai simpanan yang dijamin oleh Lembaga Penjamin Simpanan sampai Rp. 2.000.000.000,00 (dua milyar rupiah) per nasabah.

\section{Daftar Pustaka}


Djumhana, Muhammad. 2000.

Hukum Perbankan di Indonesia. Citra Aditya Bakti, Bandung.

Sembiring, Sentosa. 2012. Hukum Perbankan Edisi Revisi. CV Mandar Maju, Bandung.

Soekanto, Soerjono. 1990. Penelitian Hukum Normatif. Rajawali Pers. Jakarta.

Sutendi, Adrian. 2010. Aspek Hukum Lembaga Penjamin Simpanan. Sinar Grafika, Jakarta

Zaini, Zulfi Diane. 2012. Independensi Bank Indonesia dan Penyelesaian Bank Bermasalah. CV. Keni Media, Bandung.

Undang-Undang Nomor 10 Tahun 1998 tentang Perbankan.

Undang-Undang Nomor 24 tahun 2004 tentang Lembaga Penjamin Simpanan.

Peraturan Lembaga Penjamin Simpanan Nomor 2/PLPS/2010 tentang Program Penjaminan Simpanan (Berita Negara Republik Indonesia Nomor 97 Tahun 2010)

www.lps.go.id. 